\title{
ISSN 2335-8408
}

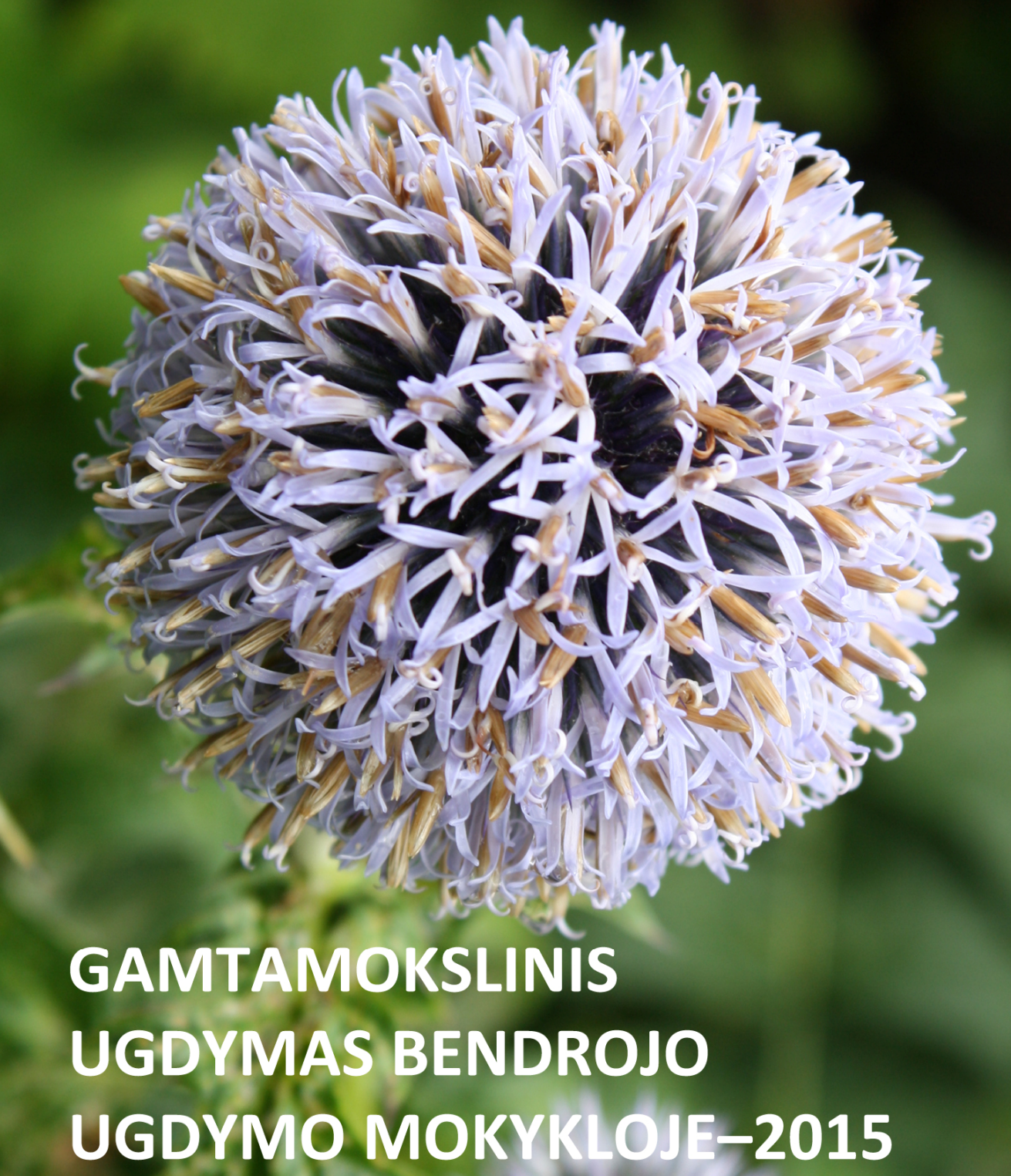

NATURAL SCIENCE EDUCATION IN A COMPREHENSIVE SCHOOL-2015 


\section{MOKSLINIS METODINIS CENTRAS „SCIENTIA EDUCOLOGICA“}

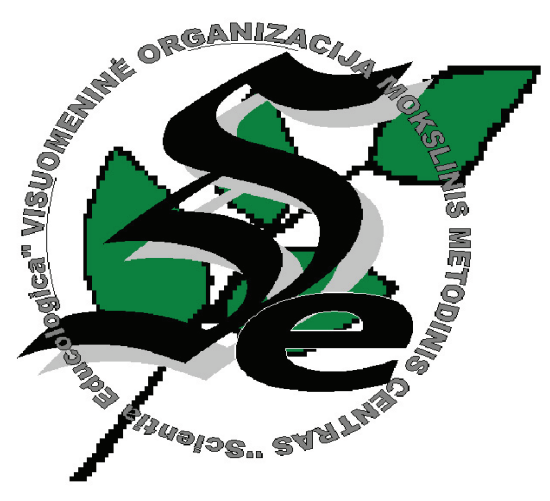

\section{GAMTAMOKSLINIS UGDYMAS BENDROJO UGDYMO MOKYKLOJE-2015}

XXI nacionalinès mokslinès praktinès konferencijos straipsniu rinkinys, Veisiejai, $2015 \mathrm{~m}$. balandžio mèn. 24-25d.

\section{NATURAL SCIENCE EDUCATION IN A COMPREHENSIVE SCHOOL-2015}

Proceedings of the Twenty-first National Scientific-Practical Conference, Veisiejai, 24-25 April, 2015 


\section{Konferencijos rengèjas / Conference Organizer}

Visuomeninè organizacija mokslinis metodinis centras „Scientia Educologica“

/ Scientific Methodical Center „Scientia Educologica“

\section{Organizacinis komitetas / Organizing Committee}

\section{Pirmininkas}

Prof. dr. Vincentas Lamanauskas, MMC „Scientia Educologica“

\section{Nariai}

Danutè Kubilienè, Veisieju gimnazija

Angelè Mizarienè, Veisieju gimnazija

Dr. Laima Railienè, MMC "Scientia Educologica"

Judita Stankutè, $M M C$ "Scientia Educologica"

Doc. dr. Violeta Šlekienè, Šiaulių universiteto Gamtamokslinio ugdymo tyrimy centras

Doc. dr. Loreta Ragulienè, Šiaulių universiteto Gamtamokslinio ugdymo tyrimy centras

Augustas Uktveris, Všl Ekologinio švietimo centras, savaitraštis „Žaliasis pasaulis“

\section{Redakcinè kolegija / Editorial Board}

Prof. dr. Andris Broks, Latvijos universitetas, Latvija

Prof. dr. Janis Gedrovics, Rygos mokytojų rengimo ir švietimo vadybos akademija, Latvija

Prof. dr. Vincentas Lamanauskas, Šiauliu universitetas, Lietuva

Dr. Naglis Švickus, Mokslinis metodinis centras "Scientia Educologica", Lietuva

Dr. Laima Railienè, Šiauliu universitetas, Lietuva

Doc. dr. Loreta Ragulienè, Šiaulių universiteto Gamtamokslinio ugdymo tyrimy centras, Lietuva

Doc. dr. Violeta Šlekienè, Šiaulių universiteto Gamtamokslinio ugdymo tyrimų centras, Lietuva

Dr. Elena Vasilevskaja, Baltarusijos valstybinis universitetas, Baltarusija

\section{Konferencijos partneriai / Conference Partners}

Viešoji j̨staiga „Ekologinio švietimo centras“ ir savaitraštis „Žaliasis pasaulis“

Lazdijų rajono savivaldybè

Lazdijų rajono Veisiejų gimnazija

\section{Konferencijos rèmèjai / Conference Sponsors}

Scientia Socialis

ISSN 2335-8408

(C) Mokslinis metodinis centras „Scientia Educologica“, 2015

The authors of the reports are responsible for the scientific content and novelty of the conference materials 